\title{
LEGAL AND FINANCIAL STIMULATION OF FOREIGN INVESTMENTS IN SERBIA
}

\author{
Bratislav Stanković* \\ Faculty of Hotel Management and Tourism, Vrnjacka Spa, Serbia \\ Nada Vignjević-Đorđević \\ State University of Novi Pazar, Serbia
}

In recent decades there have been significant changes in the legal treatment of foreign direct investments. In Serbia, like in other transitional countries, there has been liberalization of rules on foreign direct investments. Parallel to this process, the government began to approve a number of financial and fiscal incentives for foreign direct investments. In principle, it can be concluded that this approach is justified. However, some weaknesses can be observed. In terms of financial incentives, it is noticeable the existence of certain discretionary powers which could be considered excessive. Regarding tax incentives, in our opinion, the possibility of introducing incentives for export activities should be seriously considered. On the other hand, we believe that it is not justified to prescribe different customs treatment for imports of equipment brought to the capital of a company depending on whether such equipment is imported by a domestic or foreign investor. Finally, we are of opinion that it is necessary to undertake a serious study about the effects of investment incentives in order to give a proper assessment of their effectiveness and efficiency.

Key words: Foreign direct investments, Direct investments, Financial and fiscal stimulations, Directive, Foreigners, Incentives, Investments

\section{INTRODUCTION}

In theory and legal sources, there is no unique definition of foreign investments. According to a common understanding, in theory, foreign investment is transfer of funds or materials from one country (equity exporter) to another country (host country) in change for direct or indirect participation in revenues of that enterprise. Besides movement of money capital, international or cross-border movement of investments [03, 05] includes a transfer of movable or immovable property from one country to another with the goal of being used for accumulating wealth under total or partial control of the investor. Hence the idea of foreign investments comprises transfer of physical property, such as: equipment, plantations or facilities.

The international movement of equity is divided into direct investment, portfolio investment and joint ventures. The criterion by which we differ direct foreign investments from portfolio investments is a realization of permanent business interests and participation in the management of the company where the money is being invested.
Direct investments or foreign investments exist when a resident from a country (the home country) invests in the host country with the goal of obtaining a permanent interest in the enterprise (direct investment enterprise). Important features of direct investments represent the existence of permanent interest and a certain degree of control over the direct investment enterprise.

Direct investments $[01,02]$ include original transactions between two entities and all subsequent equity transactions among them and affiliated enterprises, whether they are legally independent or dependent on mother company. An investor is deemed in control if possessing $10 \%$ or more shares in basic equity of the mother company, or $10 \%$ or more voting rights in an association to be founded with new or Greenfield investments. Hence the differences regarding which forms of investment are comprised with this term, when we define direct investment. Thus, we have definitions which limit the meaning of term direct investments only on significant investments in equity of enterprises, i.e. on those investments which represent at least $10 \%$ or more of the equity of an enterprise, unlike portfolio investments which do not meet this condition. However, we 
think that such a definition can be deemed too formal and restricted. For that purpose, for the needs of this expose, we will use a broader meaning of the term direct investments, according to which, the term denotes investments in acquiring property or control over certain assets with the goal of undertaking entrepreneurship risk. A similar approach is met in professional literature, for example, Easton defines direct foreign investments [4] the following way: investments in acquiring long-term participation in business in an environment where the investor does not belong while the investor's goal is obtaining possibility to actively participate in decision-making in running the business he invests in.

This definition presumes that foreign direct investment can have a great number of forms, such as: (1) establishing corporations, (2) investing for gaining significant part in corporate equity; (3) accruing current assets for production or sales; (4) accruing fixed assets for operating long-term; (5) structural and financial linking of corporations. Of course, when selecting the form of investment, an investor can be restricted with normative framework of the host country. On the other hand, normative framework of the host country can be designed to stimulate an investor to invest exactly there and not elsewhere.

In this paper, we will give a short historical overview of Serbian stance to foreign investment, and then we will conduct an analysis of measures (financial and fiscal, including customs) which stimulate foreign investments in Serbia today, and we will try to give an assessment in context of general conditions for assessing desirability of a certain location for investment.

\section{LEGAL FRAMEWORK FOR FOREIGN INVESTMENTS IN SERBIA}

Foreign investments are not new in our corporate and normative practice [15]. Having in mind great economic significance and practical need for changing the legal regime of foreign investments, our country has seen significant changes in regulations which define this area in the last couple of decades.

Yugoslavia was the first socialist country which allowed private foreign investments back in 1967, by introducing only one legal model for foreign investments, the so-called sui generis investment, where foreign investors invested in current organizations, losing rights on invested capital, and in return got certain rights (the right to profit and registration of invested capital) proportional to this investment and success of joint venture. However, this model did not suit foreign investors because it was based exclusively on the contractual form of foreign investments, shortterm, with no possibilities of acquiring property or corporate rights.

The model of foreign investments was defined by the first special law in foreign investment, The Law on Foreign Investing in Domestic Organizations of Associated Labor, and then by the 1978 Law, which was later amended in 1984 and 1986.

The manner and conditions for foreign investments were not only defined by the law, but by The Constitution as well. The 1974 Constitution gave the basis for foreign investments (article 27 ) and then, in 1988, the Amendment XV to the 1974 Constitution removed restrictions to widen forms and possibilities of investing foreign capital and better formulate guarantees given to foreign investors.

The Government also brought the new Law on Foreign Investments, The Law on Enterprises, which enabled foreign investments propertytype. However, beside modest foreign investments, our country faced strong and growing competition. Since the 1988 Law on Foreign Investments, through the 1994 Law on Foreign Investment, up until today, there has been an ongoing liberalization of the regime of foreign investments.

For the area of foreign investments, beside Law on Foreign Investment, as basic law in Serbian legislature, laws on corporations, on stateowned-private partnership and concessions, foreign currency dealings and loan jobs with foreign countries, on customs, accounting and other laws are relevant.

Firstly, in Serbian legislature, The Law on Foreign Currency Dealings defines direct investment as an investment by a resident abroad or a nonresident in the country in a legal entity, with the goal of participating in operations of the entity. What is understood under investment: founding a legal entity, branch or a representative office; buying shares of a legal entity, adding capital to a legal entity, any other form of investment, where the investor gains at least $10 \%$ of voting rights, within not longer than a year from original investment in case of successive investment (for 
reaching the $10 \%$ threshold).

The Law on Foreign Investment $[9,10$, p. 211221,11 , p. $87-103$ ], as the basic law, is characterized by liberalization and deregulation of foreign investment regime. This law and the way it regulates foreign investments is necessary even today and will be until complete affirmation of market economy and all its elements, when specific features of the issue will be naturally incorporated in the legislature on trade associations and foreign currency dealings.

Basic features of legal regime applied on foreign investments according to the 2002 Law on Foreign Investment will be analyzed through legal solutions which represent basic determinants of legal regime of foreign investments in Serbia, regarding the following issues: the idea and forms of foreign investments, basic principles on which the law is based, protection of foreign investors' rights and stimulations for foreign investments.

Foremost, foreign investment in Serbian legislature is defined very broadly, including all comparative standard forms of foreign investment, with no limits to investments, except in production and sales of weapons and forbidden zones. Moreover, an investment is investment in a domestic enterprise, by which a foreign investor acquires shares or bonds in its equity, the establishment of a new enterprise, but it is also acquiring any other property right of a foreign investor, by which he realizes his business interests in Serbia, including his participation in privatization. The investment of a foreign investor can be in a foreign currency, things, intellectual rights, securities and other property rights.

Foreign investment in Serbia [14, p. 243-258, 16 , p.3-11] also consists of the following forms of foreign investment: 1) Investment in Serbian enterprises by which a foreign investor acquires shares or stocks in their equity; 2) establishing an enterprise, solely or with other foreign or domestic investors; 3) concessions and 4) B.O.T. (Build Operate and Transfer) jobs, as special forms of foreign investment. In this context, one should bear in mind that company regulations still do not foresee special conditions for status changes where foreign corporations would participate beside domestic ones. Accordingly, we think that conditions are not ripe yet for foreign legal entities to acquire capital of domestic corporations in status change procedures. Since enabling cross-border status changes has become an ob- ligation of the EU members, we expect Serbian legislature to foresee such a possibility during further integration activities.

One should point out that there are different contract investments in the international business, such as joint ventures, equity investments, equity joint ventures.

Investments of property type occur in two forms: as portfolio foreign investments and direct foreign investment. Direct foreign investments are of particular interest to Serbia, so they have been subsidized since 2006, especially Greenfield and Brownfield projects in industry, marketing, research and development.

The Law on Foreign Investments, unlike other solutions, foresaw the very limit according to which a foreigner cannot have a majority share in corporations producing and selling weapons and military equipment, and in those corporations operating in forbidden zones.

Then, The Law on Foreign Investments [17, p. 286-291, 18] is based on certain principles. According to the first one, the principle of freedom of foreign investments, a foreign investor establishes an enterprise, i.e. invests in enterprises aiming to operate with a profit, beside above-mentioned limits. The second one, especially important principle, is national treatment, a guarantee of protection of foreign entities to the same extent as domestic ones. The third principle deals with acknowledgment of acquired rights and their continuity so that rights acquired at the time of registration cannot be reduced by a later change of regulations. The fourth principle is a strictly defined priority of treatment of foreign investments which comes out of concluded and ratified international contracts relating to treatment foreseen by the law. The fifth principle, the autonomy of contracting parties, deals with both contracts and the way of resolving disputes. In the corps of principles of foreign investments, a special significance goes to a complex system of sensible and commonly accepted rights, guarantees and benefits of foreign investors.

Furthermore, the system of protection, foreseen by the Law on Foreign Investments, envelops not only specific right related to currency conversion, accounting in accord with international standards and the right to transfer profit and property abroad, but also legal guarantees for foreign investors. Free currency conversion understands the right of a foreign investor to convert domes- 
tic currency into a foreign one, to freely pay and keep foreign currency on the bank account in accord with the Currency Law.

A foreign investor has the right to keep accounting books in accord with international accounting and audit standards, besides obligatory accounting in accord with domestic regulations.

The right of a foreign investor on profit and property transfer abroad is proscribed so that a foreign investor can freely, with no delays, transfer all financial and other assets in convertible currency, after paying his liabilities and in accord with domestic regulations, especially profit and property which belongs to him after shares or stocks or a part of the corporation with foreign investment. On the other hand, Serbian legislature $[23,24,25,26,31]$ provides legal guarantees for foreign investors: protection from expropriation and other measures of the state with equal effect in accord with The Law on Foreign Investment. The Expropriation Law and protection from transfer risk is in accord with The Law on Foreign Investment and regulations on currency dealings.

In the end, The Law on Foreign Investments $[23,24,25]$, for the purpose of stimulating foreign investments, defines only general stimulating measures and benefits. The stimuli regarding the free import of objects of foreign investments, like customs and tariff benefits, are subject to customs and tariff regulations.

In accordance with the above-mentioned, it is our opinion that legal framework leaves quite enough possibilities for foreign investors to undertake direct investments in Serbia. Hence, the level of direct investments will depend on other elements influencing forming a convenient investment climate such as investment security, political stability and measures for investment stimulation. Surely, the widest possibilities for stimulating foreign investments are in financial and fiscal areas. We will deal with these issues further on in this paper, together with customs benefits for investments in Serbia.

\section{STIMULATIONS AND BENEFITS FOR FOREIGN INVESTORS}

In modern international practice, the common solution is that investment incentives are similar for both domestic and foreign investors. Giving stimulation to only domestic investors is often opposed to undertaken international commit- ments, such as membership in the WTO. On the other hand, although exclusive direct investment stimulai for foreign investors would not be opposed to international commitment of countries, practical experiences tell us that it could produce significant negative side effects, such as jeopardizing competitiveness of domestic investors, causing negative attitude towards foreign investors in the public, illegal behavior of domestic businesspeople for gaining competitive advantage ahead of foreign investors and transfer of funds of domestic investors abroad for investing abroad.

However, besides formal neutrality in providing incentives, one should have in mind that there are methods for directing stimulation to foreign investors. Such is the case with prescribing conditions for providing stimuli only foreign investors can meet, i.e. regarding the amount of investment or a sector where an investment is made. On the other hand, although some measures, at first sight, discriminate foreign investors, it is not the case in reality. For example, the regulation which stipulates that tax stimuli can be used by a domestic corporation (even those owned by a foreign entity), while the same cannot be said of branches of foreign ones basically does not represent discrimination of a foreign entity because they can fairly easily establish a corporate branch in Serbia.

\section{Financial stimulations}

Distribution of financial stimuli for attracting direct investments is regulated by Regulation of Conditions and Manner of Attracting Direct Investments. The decision on approving payment of stimulating funds is brought after a completed tender procedure. The tender is prepared and published by Agency for Foreign Investments and Export Promotion. Generally, one could object that deadlines for opening tender procedure are not sufficiently clear so one can get the impression that the Agency for Foreign Investments and Export Promotion has wide discretion authorities.

An investor can qualify for stimulus if he invests in: (1) Production sector where minimum investment is 1,000,000 Euros and opening at least 50 new jobs; (2) production sector and devastated areas and areas of special interest with a minimum of 500,000 Euros and creating 50 new jobs and (3) service sector which can be subject of international trade with minimum amount of 
500,000 Euros and creating 10 new jobs.

The amount of financial stimulus is determined by the number of new jobs opened within 3 years and by the form of investment, place of investment and meeting other criteria, ranging from 2,000 to 10,000 Euros per new job. Conditions for determining the precise amount of money have not been defined so the issue over authorization can arise, as well as in the case of opening tender procedure. For investments over $50,000,000$ Euros and creating at least 300 jobs, funds of $20 \%$ of total investment are assigned, and for investments over 200,000,000 Euros and creating 1,000 new jobs, the funds are $25 \%$ of total investment.

The user of funds concludes a contract with a Ministry in charge of the economy and regional development, which defines mutual rights related to use of money, the amount of money assigned and reimbursement. Moreover, the user of funds must enclose a banking guarantee.

On the basis of above mentioned, one can conclude that our legislative leaves wide possibilities for giving financial stimuli aiming to enhance direct investments, and that, generally, no difference is being made between domestic and foreign investors. But, when we look at conditions for certain stimuli, it is completely clear they were designed for foreign investors, e.g. stimulus for investments over 200 million Euros. Of course, having in mind the significance of attracting significant foreign investments, we think that such a regulation is totally justified. We think such a stimulus can be viewed positively with corrections which would remove ambiguities regarding excessive discretion authorities. Finally, it is necessary to analyze in detail the extent of their effectiveness and efficiency.

\section{Fiscal stimulations}

Tax regulations $[04,06]$ in Serbia foresee a great number of different tax stimuli intended to increase the level of investments and to realize other socially acceptable goals, such as protecting the environment. We will here discuss only tax stimuli foreseen by The Law on Tax on Profit of Legal Entities (further: LTPLE), and its significance on direct investments. We also deal with the issue of eventual introduction of special tax stimulus for exporters. In many countries, export is significant for the economic stability of each country, especially if a country has negative foreign trade balance.

\section{Stimulation for big investors}

Comparatively legally speaking, it is common practice to approve tax exempt for investments in activities which exceed prescribed value, usually very high for local conditions. The conditions for approving tax-exempt for investment can differ depending on the area of investment. For investments in undeveloped areas and other areas of special interest, tax-exempt can be approved under more convenient conditions. The reason for limiting rights on tax-exempt for investing in businesses is establishing a connection between tax revenues and achieving goals of economic policy. We think this is reasonable, under the condition that for smaller investments, appropriate tax stimuli are enabled, in form of tax-exempts or tax loans.

LTPLE foresees two basic forms of tax-exempt for investing into fixed assets:

"Big" tax-exempt for investing in Serbian economy. This tax-exempt is given to a taxpayer over a 10-year period from the first year with realized profit under the following conditions: (1) The taxpayer invested in his fixed assets, i.e. third party instead in fixed assets of the taxpayer the amount of over $800,000,000$ RSD, not counting the equipment already in use in Serbia; (2) the taxpayer uses investment in a registered business in Serbia; (3) the taxpayer additionally employs at least 100 people during investment period. Tax-exempt is approved proportionally to the investment. There are also measures for preventing fraud. We think it is especially important that the taxpayer has the right to use the tax loan for investing in fixed assets until he fulfills the conditions for tax-exempt.

Small tax-exempt for investing in special interest for the Republic. This tax exempt is given to a taxpayer for 5 years from the first year with taxable profit under the following conditions: (1) The taxpayer invested in his fixed assets, i.e. the third party invested in taxpayer's fixed assets the amount larger than $800,000,000$ RSD; (2) the taxpayer uses $80 \%$ of value of fixed assets in the registered business in an area of special interest for the Republic; (3) at least $80 \%$ of the full-time employees have residence in the area of the special interest for the republic; and (4) the taxpayer additionally employs at least 5 people during investment period. Tax-exempt is proportional to the investment. Also, regulations have been brought against fraud. However, conditions 
for applying this exempt have not been fulfilled because Serbian laws do not define an area of special interest for the Republic.

\section{Incentives for investing into fixed assets}

LTPLE foresees the right to a tax loan regardless of total amount of investment. This tax incentive is given in a form of tax loan the amount of which depends on: (1) the amount of investment; (2) the status of the taxpayer; and (3) the business of the taxpayer. Accordingly, we can distinguish the following basic forms of tax loan on the basis of investment in a business:

- Standard. Applied to taxpayers sorted into big or medium legal entities. Tax loan is approved in the amount of $20 \%$ of the investment and cannot be larger than $50 \%$ of the tax in the year of the investment. The unused loan amount can be transferred on account of future accounting periods, but not longer than 10 years.

- We will notice that this tax incentive is very generous and twice as big as the situation where an investment would be acknowledged as deducted item for determining taxable profit. From point of view of the amount of the incentive, the other two forms are even more convenient compared to the standard one;

- Tax loan for small legal entities. It is applied on taxpayers sorted into small legal entities. A tax loan is approved in the amount of $40 \%$ of the investment, and it cannot be bigger than $70 \%$ of the calculated tax in the year of the investment. Unused loan can be transferred on account of profit from future accounting periods, but not longer than 10 years;

- Privileged. It is given to taxpayers in Registry of Businesses sorted in one of the businesses foreseen in article $48 \mathrm{a}$ item 1 of the LTPLE. The tax loan is approved in the amount of the investment, with no limits regarding tax in the year of the investment.

We think that above-described incentive is extremely generous and represents a significant contribution to tax competitiveness of Serbia ahead of other countries the regulations of which we analyze. Viewed as a whole, together with tax stimulation [22, p. 285-298] given to big investors, it makes Serbia a country that gives most convenient stimuli for foreign investments.

\section{EXPORT STIMULATION AND INTERNATIONAL COMMITMENTS OF SERBIA}

Revenues abroad can be made by: (1) Exporting or (2) direct business operations abroad. For every country, it is more convenient that domestic investors make revenues by exporting because that increases the level of domestic business operations. However, possibilities for stimulating export are often limited by international commitments of a country.

In this regard, the most important commitments for Serbia are the ones made to WTO and Agreement on Amendment and Admission on Free Trade in Central Europe - CEFTA 2006 (further: CEFTA), a treaty signed by all neighboring countries non-member states of the EU. As a rule, membership in WTO forbids stimulating export by measures directly connected with the taxation of businesses. For precision, one should have in mind that, according to WTO rules, not all exporting stimuli are forbidden. We think that, in this context, Serbia has no rights and obligations coming out of the fact that Yugoslavia was a signee of the GATT.

On $19^{\text {th }}$ June 1993, The GATT council passed the decision stating that FRY: (1) cannot automatically keep the status of contractual party which SFRY had in the GATT; (2) cannot participate in work of the GATT organs; and (3) it is necessary that FRY submits an application for status of contractual country.

Beside above mentioned, negotiations are under way about Serbia's request for admission into WTO, led in accord with article 12 of the Agreement on Founding WTO, i.e. according to the procedure for admission of countries without the previous status of contractual countries in the GATT. One could conclude that, by submitting a request for admission to WTO, Serbia silently accepted the attitude of the GATT Council on discontinuity between former Yugoslavia and its successors regarding membership in the GATT. This approach we deem correct because then Serbia would keep all obligations former Yugoslavia had as a GATT member, while it could not use any rights on those grounds.

The question is if there is a limit for stimulating export by membership in CEFTA [27]? We think that the answer can be found in article 21 of CEFTA. This article stipulates that providing government help is not in accord with CEFTA, 
and that discord will be measured on principles for governmental help in the EU, especially article 87 of the Founding Contract.

However, CEFTA limits possibilities for providing governmental help. Article 87 of the Founding Contract in the EU stipulates that jeopardizing competition by providing help to certain businesses or industries is forbidden, while CEFTA is limited to favoring certain goods. According to that, we think that CEFTA does not limit the right of countries to give stimuli to businesses as long as these stimuli do not directly influence prices of certain goods.

Therefore, measures to promote export where we reduce taxation of a company's profit in proportion with its exports are not in discord with CEFTA, if they are not limited to the export of specific goods or categories of goods.

Of all former Yugoslav republics CEFTA members, only Bosnia and Herzegovina used the possibility of stimulating exports. They foresee profit tax exempt for a company which exports over $30 \%$ of its goods. Therefore, by applying this stimulus for a non-resident investor which accrues and repatriates profit from Bosnia and Herzegovina, the total tax burden is:

- Reduced to tax after dividend (5\%) in the case when a non-resident investor operates through a resident company; and

- fully removed in the case when a non-resident investor operates through permanent business units.

Because of, beside very convenient taxation [8], very low threshold of use, we think this stimulus represents a strong means of promoting and attracting exports. However, the question is if this is too convenient because: (1) it does not directly link volume of exporting to degree of tax deduction; and (2) because of prescribed low threshold of use, it creates significant possibilities for tax planning and profit tax deduction on grounds of activities not related to exporting. However, regarding promoting exporting for the development of undeveloped countries, this stimulus could be deemed justified.

As for Serbia, we think we cannot expect measures which would in any manner jeopardize its admission to WTO and the EU. It is not realistic to expect measures for promoting exports contradictory to regulations of these organizations, regardless of positive effects these measures could have. On the other hand, if a decision is made that LTPLE accepts regulation on promoting exports, we think that, unlike Bosnia and Herzegovina, for the purpose of preventing unacceptable tax planning, stimulus could largely be related to proportion of exports and other revenues, i.e. by determining that a resident company is tax free: (1) in percentage of export revenues in total revenues, if that percentage is lower than 70\%; and (2) in whole, if export revenues participate at least with $70 \%$ of total revenues.

\section{Financial system attractiveness}

The regulatory framework for the financial market must continue development in order to achieve macroeconomic stability. Since 2006, Serbia has successfully reached an agreement with MMF and achieved a credit rating of $\mathrm{B}+$, indicating stable to a positive outlook. In the same period, World Bank, OECD, EBRD, and other referent institutions announced Serbia as the leader in Central and Southeast Europe.

Serbia offers many advantages to foreign investors such as strategic positioning, the lowest tax rate [21. p. 93-101, 28,29] on profit enterprises in Europe, and a simple procedure for export trading and production. The EU has recommended the development of company law and an action plan based on expansion transparency. There are two important areas for corporate governance: financial services regulation and voluntary regulation. Corporate governance refers to the transparency of public information; equal treatment of auctioneers; a limited role of interest groups in corporate management; and a responsible management board.

The regulatory framework for the financial market function was the condition sine qua non, but not enough one. It was necessary first to realize the level of keeping development and satisfied macroeconomic stability, which is in enough measure done.

Beginning 2006 successfully closed the broaden agreement with MMF [7] and the other way amendment credit rating Serbian from $\mathrm{B}+$ stable outlook (November 2004) on BB- positive outlook (S\&P credit ratio). In the same period in many reports off: World Bank, OECD, EBRD and others referent institutions Serbia is announced leader compared with countries in Central and Southeast Europe, by fast conducting reforms. The advantages Serbia offered to foreign inves- 
tors, by the order SIEPA organizing are:

- Strategic positioning on Europe, Asia and Near East,

- Duty-Free approach to Free Trade Zone in southeast Europe - 60 mil consumers

- The one country out of $\mathrm{CIC}$ - Community of independent countries sight the free trade agreement with Russian Federation

- Serbia is not the member of EU, which gave more flexibility and advantages for investment

- Lowest tax rate on profit enterprises in Europe $(10 \%)$

- Educated and chip label

- Most percentage citizens spoken English in southeast and central Europe

- Stable economy

- Simple terms for foreign investment

- Simple procedure for export trading and production and founded enterprises included stay foreign terms, registration companies and customs

- Getting into a partnership for peace in December 2006.

\section{Customs stimulation}

Customs law foresees exempt for importing new equipment $[11,12,13]$ not produced in Serbia and is imported for new or expansion of new production, production modernization, the introduction of new technology or improvement of existing one, except passenger cars and gambling devices. When you use this customs-exempt, you cannot alienate the equipment before three years, rent it or use it otherwise, except for purposes it was exempted, before the import fees are paid.

These goods cannot be given as collateral, loan or security for any liability [30]. Beside legally binding conditions for import fees exemption, Decision on determining goods free of import fees foresees that you have to submit the following to the customs authorities: (1) Proof of registry in Registry of businesses; (2) statement of user that equipment is imported for new production or expansion of current one and introduction of new technology or improvement of existing one and is used for your own needs exclusively; and (3) certificate from Commerce of Chamber of Serbia that such equipment is not produced in Serbia.
Table 1: Financial support and tax relief for investors

\begin{tabular}{|c|c|}
\hline \multicolumn{2}{|c|}{$\begin{array}{l}\text { Summary of financial support schemes and } \\
\text { tax relief forms }\end{array}$} \\
\hline & $\begin{array}{l}\text { Grants from } € 2,000 \text { up to } \\
€ 10,000 \text { per }\end{array}$ \\
\hline \multirow[t]{2}{*}{$\begin{array}{l}\text { Financial } \\
\text { Incentives }\end{array}$} & $\begin{array}{l}\text { New job created } \\
\text { Numerous support } \\
\text { schemes offered by the } \\
\text { National Employment } \\
\text { Service } \\
\text { A } 10 \text {-year corporate profit } \\
\text { tax holiday for large } \\
\text { investments } \\
\text { Corporate profit tax credits } \\
\text { up to } 80 \% \text { of the fixed } \\
\text { assets investment }\end{array}$ \\
\hline & $\begin{array}{l}\text { Tax reduction for new } \\
\text { employment } \\
\text { A 5-year corporate profit } \\
\text { tax holiday for concessions }\end{array}$ \\
\hline $\begin{array}{l}\text { Tax } \\
\text { Incentives }\end{array}$ & $\begin{array}{l}\text { Carrying forward of losses } \\
\text { over up to } 10 \text { years } \\
\text { Accelerated depreciation } \\
\text { of fixed assets } \\
\text { Salary tax and social } \\
\text { insurance charges } \\
\text { exemptions for employees } \\
\text { under } 30 \text { and over45years } \\
\text { Annual income tax } \\
\text { deductions up to } 50 \% \text { of } \\
\text { the taxable income } \\
\text { Customs-free imports of } \\
\text { equipment based on } \\
\text { foreign investment }\end{array}$ \\
\hline
\end{tabular}

Beside Customs Law, Law on Foreign Investments foresees customs-exempt for importing equipment invested by a foreign entity, except passenger cars and gambling devices. Decision on determining goods exempted from import fees, documentation for realizing above mentioned rights is more closely defined: (1) certificate from Registry of businesses on amount of foreign investment in equity of a business, i.e. on change of equity of a business with foreign investment on grounds of re-investment of profit, as well as of date of registration of foreign investment; and (2) statement on constructing premises for using the equipment, i.e. statement on date of starting activities which are invested in, a contract or a decision on re-investing profit, if 
investment is made on basis of re-investment of profit. Also, Customs authorities issued a special act which more closely describes the procedure of realizing rights on the exemption from paying import fees on equipment which is a foreign investment.

Regarding this exemption, we think one should consider the possibility of widening its application on domestic investors, since there are no economic reasons for different treatment of domestic and foreign investors regarding importing equipment which will be entered in a company's equity. In both these cases of customs fees exemption, customs monitoring is applied for three years from the day of activating the goods.

\section{CONCLUSION}

In the last couple of decades, Serbia has passed the road from limiting possibilities of foreign investment to stimulating them. In this period, awareness has grown about the usefulness of foreign investments for each country's economy, where its positive effects outweigh the negative ones. Therefore, a great number of fiscal and financial incentives have been designed. Generally, one could conclude this approach is correct.

However, certain weaknesses can be seen. Regarding financial stimulations, there are certain discretion authorizations which can be deemed excessive. As for tax incentives [19, p. 205-215, 20 , s. $50-57,21$, s. $93-101$, 22 , s. $285-298]$, we think one should consider stimulating exports. On the other hand, we do not think proscribing different customs treatment for importing equipment which is entered into a company's equity depending on whether a foreign or a domestic entity does it. Finally, we think it is necessary to carefully study the effects of given tax stimuli in order to bring judgment about their justification, i.e. their effectiveness and efficiency.

\section{REFERENCES}

1) Analytic approach to macroeconomic and fiscal tendencies, (2006) Ministry of Finance, Republic of Serbia, p. 103-148

2) Bofinger, Peter and Wollmershauser, (2001) Is there a third way to EMU for the accession countries? [Online] Available: www.uni-magdeburg.de retrieved on 11.01.2013

3) Bühler, Konrad, (2001) State Succession and Membership in International Organizations. Legal Theories versus Political Pragmatism, Kluwer Law International, p. 93

4) Easson, Alex (2004) Tax Incentives for Foreign Direct Investment, Kluwer Law International, p. 119-127

5) Encyclopedia of Public International Law, Amsterdam; New York: North-Holland Pub. Co.; New York, Vol. 8.

6) Frommel Michael, (2006) Volatility Regimes in Central and Eastern European Countries, [Online] Available: www.wiwi.uni-hannover. de retrieved on 17.05.2014

7) IMF, Monetary and Exchange Rate Policies of the Euro Area, IMF Country Report No.01/06, Washington, D.C.

8) Lyons, Susan (editor) (1996) International Tax Glossary, Third Edition, Amsterdam, The International Bureau of Fiscal Documentation

9) OECD (1999) Benchmark Definition of Foreign Direct Investment, Third Edition

10) Popović, D., (2008) Tax Law, Faculty of Law University of Belgrade, Official Gazette RS, p. 21

11) Petrović, J., (2002) Legal aspects of foreign investment, Law and Economy, Belgrade, 14/2002 p. 85-91

12) Regional Policy in the book: The Economics of the European Union Policy and Analysis, Third Edition, Edition by Mike Artis, Frederick Nixson, First Published, New York, 2003, p. 321-343

13) Sornarajah, M., (2004) The International Law on Foreign Investment, Second ed., Cambridge, p. 156-187

14) The International Bank for Reconstruction and Development/ The World Bank (2003), Doing Business 2007: How to reform, comparing regulation in 175 economies 
15) Tondl G., (2003), Regional Policy in the book: The Economics of the European Union Policy and Analysis, Third Edition, Edition by Mike Artis, Frederick Nixson, First Published, New York, p. 123-141

16) The International Bank for Reconstruction and Development, The World Bank. (2006) Doing Business 2007: How to reform, comparing regulation in 175 economies

17) Vilus, J., Carić, S., Šogovor, S., Đurđev, D., Divljak, D., ( 2008) International Commercial Law, Novi Sad, Publishing Center, p. 236254

18) Vukadinović, R., (2012) International Business Law, Kragujevac, p. 81-116

19) Vignjević Đorđević N., (2013) Institutional harmonisation and developing markets in the Central Balkans, Facta Universitatis, Series: Economics and Organisation, University of Niš, Facta 2013 3/2010 p.291-298

20) Vignjević Đorđević N., Hamzagić A., (2013) The role of financial functions in preventing financial crisis, Conference „Problems of social and economic development of business“, University „Alfred Nobel“, Dnjepropetrovsk November 14-15, Ukrain, UDK 330,637 BBK 65 p. $50-57$

21) Alibašić M., Vignjević Đorđević N., Jevtić S., (2013) Tax authorities and procedures - effects on MNK - Transparency and International experience, Ekonomika, Ekonomski fakultet Niš, p. 93-101

22) Vignjević Đorđević N., Stanković B., (2013) Public-private partnerships and concessions, as special forms of foreign investments in Serbia, Economy and Market Communication Review, EMC Review, vol III, No II, Banja Luka p. 285-298

23) The law on the investment of foreign entities in the domestic organization of associated labor, Official Gazette SFRJ, No. 22/1973

24) Foreign Investment Law, Official Gazette SFRJ, No. 77/1988

25) Foreign Investment Law, Official Gazette SRJ, No. 79/1994 i 29/1996

26) Foreign Investment Law, Official Gazette SRJ, No. 3/2002 i 5/2003

27) Law on Ratification of the Agreement on amendment of and accession agreement on free trade in Central Europe - CEFTA 2006 (Official Gazette RS - International Agreements br.88/2007)

28) Law on Income Tax, Official Gazette $\mathrm{BiH}$, No. 97/2007 i 14/2008

29) Law on Corporate Income Tax, Official Gazette, No. 18/2010

30) Decision on determining the goods to which they do not pay import duties, Official Gazette RS, No. 27 i 48/2010

31) Regulation on the terms and conditions for attracting direct investment, Official Gazette RS, No. 34/2010 i 41/2010

Paper sent to revision: 14.11.2016.

Paper ready for publication: 28.02.2017. 